UDC 656.025.4/.6:656.073.5

ORCID ID: http:// orcid.org/ 0000-0001-5849-9033

DOI 10.33082/2226-1893-2019-3-132-139

\title{
MECHANISMS OF CUSTOMS FORMALITIES IN THE INTERNATIONAL TRANSPORT SYSTEM
}

\author{
V.M. Piterska \\ Doctor of Science (Engineering), Associate Professor, Professor of the Department \\ «Port Operation and Cargo Works Technology» \\ e-mail:varuwa@ukr.net
}

Odessa National Maritime University, Odessa, Ukraine

\begin{abstract}
The effective implementation of customs operations is one of the main manifestations of the high degree of development of the logistics system in terms of the formation of an international transport complex while ensuring national security of the state. The technology of customs and transport regulation should ensure the acceleration of goods turnover and passenger traffic, which is one of the main tasks of most customs agencies of foreign countries caused by various integration processes in the field of tourism development, the international distribution of labor, the creation of common labor markets, as well as the organization of an international logistics system. The introduction of balanced, stable technologies of customs control and customs clearance creates the conditions for the stable functioning of the logistics system, its strengthening, helps to accelerate the process of goods distribution, develop the export potential of domestic products, deepen integration in the European and world systems and enhance participation in international customs organizations.
\end{abstract}

Keywords: transport system, customs formalities, freight traffic.

УДК 656.025.4/.6:656.073.5

ORCID ID: http:// orcid.org/ 0000-0001-5849-9033

DOI 10.33082/2226-1893-2019-3-132-139

\section{МЕХАНІЗМИ ЗДІЙСНЕННЯ МИТНИХ ФОРМАЛЬНОСТЕЙ В МІЖНАРОДНІЙ ТРАНСПОРТНІЙ СИСТЕМІ}

\section{В.М. Пітерська}

доктор технічних наук, доцент, професор кафедри «Експлуатація портів і технологія вантажних робіт»

Одеський національний морський університет, Одеса, Украйна

Анотація. Ефективне здійснення митних операцій $\epsilon$ одним 3 головних проявів високого ступеня розвитку логістичної системи з точки зору формування міжнародного транспортного комплексу при забезпеченні національної безпеки держави.

(C) Piterska V.M., 2019 
ВІСНИК

ОДЕСЬКОГО НАЦІОНАЛЬНОГО

МОРСЬКОГО УНІВЕРСИТЕТУ

№ 3 (60), 2019
HERALD

OF THE ODESSA NATIONAL

MARITIME UNIVERSITY № 3 (60), 2019

Впровадження врівноважених, стабільних технологій митного контролю i митного оформлення створює умови для функціонування в стабільному стані логістичної системи, ї̈ зміџнення, сприяє прискоренню прочесу руху товару, розвитку експортного потенціалу вітчизняної продукції, поглиблення інтеграиії в європейську і світову систему $i$ активізаиії участі в міжнародних митних організаціях. Раціональне використання логістичної концепчії руху товару створить умови для активізаџії вітчизняного науково-технічного та інновачійного потенціалів, залучення підприємств до ефективної співпрачі; впровадження механізму збереження і відновлення інтелектуальних, енергетичних, трудових, природних ресурсів на території держави і стимулювання найбільш ефективного їх використання; забезпечення збалансованості логістичної системи з урахуванням визнаних у міжнародній практииі заходів для полегшення торгівлі, збільшення транзитної привабливості країни, прискорення товарообігу та пасажиропотоку через митний кордон, недопущення ввезення на територію держави неякісних товарів, використання $i$ споживання яких становить небезпеку.

Ключові слова: транспортна система, митні формальності, вантажопотік.

УДК 656.025.4/.6:656.073.5

ORCID ID: http:// orcid.org/ 0000-0001-5849-9033

DOI 10.33082/2226-1893-2019-3-132-139

\section{МЕХАНИЗМЫ ОСУЩЕСТВЛЕНИЯ ТАМОЖЕННЫХ ФОРМАЛЬНОСТЕЙ В МЕЖДУНАРОДНОЙ ТРАНСПОРТНОЙ СИСТЕМЕ}

\section{В.М. Питерская}

доктор технических наук, доцент, профессор кафедры «Эксплуатация портов и технология грузовых работ»

Одесский наџиональный морской университет, Одесса, Украина

Аннотация. Эффективное осуществление таможенных операций является одним из главных проявлений высокой степени развития логистической системы с точки зрения формирования международного транспортного комплекса при обеспечении начиональной безопасности государства. Внедрение уравновешенных, стабильных технологий таможенного контроля и таможенного оформления создает условия для функиионирования в стабильном состоянии логистической системы, ее укрепления, способствует ускорению процесса товародвижения, развитию экспортного потенциала отечественной продукции, углублению интеграчии в европейскую и мировую систему и активизации участия в международных таможенных организачиях.

Ключевые слова: транспортная система, таможенные формальности, грузопоток. 
Introduction. The modern development of the logistics system has a clear tendency to integrate the national transport system into a single global economic complex. Foreign trade relations have become an important factor in the growth of transport and technological services for the movement of goods across the customs border of Ukraine.

The active development of the international transport system requires the creation of new approaches to the development and adoption of effective managerial decisions regarding the use of logistics principles in the formation of the technology of customs and transport services for cargo flows [1].

The effective implementation of customs and transport activities is an important direction in the development of trade relations. A special role is given to state regulation of the process of goods distribution by controlling services.

The process of globalization of international relations causes a quantitative and qualitative increase in commodity, information, financial flows in the global space [2]. In these conditions, timely delivery of goods is an essential factor in the functioning of a developed logistics system.

Formulation of the problem. In the system of state management of the process of moving goods across the customs border of Ukraine, an important place is occupied by customs activity. This is due to the influence of the customs authorities on the formation of the logistics system of distribution.

Customs policy and customs, taking into account international standards, are the main levers of the manifestation of state sovereignty in solving domestic problems of the country, as well as the formation of an international legal position.

The rapid development of foreign trade relations has led to the emergence of new approaches to the development of effective strategies for the functioning of the system of international relations. An important direction in regulating the process of goods distribution is the formation of a logistic concept that helps to reduce the time of delivery of goods from the sender to the recipient.

Analysis of the main achievements and literature. In order to accelerate the turnover of goods and passenger traffic in the context of a logistic approach, the customs authorities of Ukraine have important tasks to implement and control customs affairs, apply tariff and non-tariff regulation measures when moving goods across the customs border of Ukraine. An important aspect in the functioning of the transport system is the implementation of regulation of the direction of goods distribution taking into account risk situations [3-5].

It should be noted that Ukraine occupies a favorable geopolitical position, has a developed network of railways and highways, and modern seaports. These factors enable the state to take one of the key positions in establishing transport links between the countries of Europe and Asia in the implementation of production and transport activities that contribute to stimulating the deve- 
lopment of the international trading system, taking into account the requirements for ensuring the country's security and protecting national interests [4-6].

Moreover, for the rational development of the logistics system, it is necessary to simplify customs procedures in accordance with the principles of the Kyoto Convention, as well as the requirements of the World Trade Organization $[7 ; 8]$.

At the same time, possible customs threats, their impact and negative consequences on the goods distribution process, the country's security, national interests, the protection and implementation of which the customs service is designed to provide, should be taken into account [9-11].

A logistic approach to the transport of goods from the position of customs regulation involves the implementation of basic customs operations related to the control and processing of goods transported across the customs border of Ukraine, accrual, collection of taxes and fees [12].

Formulation of the purpose of the article. The purpose of this article is to consider the logistic approach in organizing the delivery process, taking into account customs and transport regulation of the procedure for moving goods across the customs border.

Materials of research. The liberalization of foreign economic activity, the creation of a developed logistics system, the improvement of state regulation of transport and production activities, reduction of tariff and nontariff restrictions, reduction of duties to the optimal minimum, simplification of customs, export-import procedures with their simultaneous computerization will lead to a decrease barriers, as well as the dynamic development of the international trade and transport system.

Improving the activities of customs authorities in the context of a logistic approach to goods distribution consists in rationalizing forms and methods of customs control and clearance, namely, in establishing methods that meet customs standards and rules recognized in international practice, contribute to the acceleration of goods turnover and passenger traffic, do not harm legal rights and interests of the subjects of displacement, as well as ensure the rigorous implementation by the customs authorities of the tasks assigned to them, taking into account global tenders The use of the system of electronic declaration and risk analysis of the occurrence of customs violations.

An integral part of the effective functioning of the logistics system is the observance by the subjects of movement of requirements for the quality of goods and services provided by international and state quality systems.

The technology of customs and transport regulation should ensure the acceleration of goods turnover and passenger traffic, which is one of the main tasks of most customs agencies of foreign countries caused by various integration processes in the field of tourism development, the international distribution of labor, the creation of common labor markets, as well as the organization of an international logistics system. 
This system involves the implementation of joint customs control according to a single technological scheme, which contributes to the establishment of contractual relations with neighboring states, the development of international cooperation in the field of customs through participation in world customs and trade organizations.

In order to ensure the efficient functioning of the transport system in the context of a logistic approach to customs regulation, one should take into account the procedure for verifying certificates of origin of goods by checking the specified document for authenticity by means of an examination, verifying the correctness of filling in the column, presence of an imprint of the seal and signature of the authorized person, as well as the place and date issuance.

Another area of rational interaction between the customs and the transport system is the unification of customs control procedures and clearance of goods belonging to both enterprises, organizations, institutions of various forms of ownership, as well as to citizens, by introducing technological control schemes that comply with modern international standards.

Speeding up the process of transporting goods across the customs border of Ukraine under the conditions of a logistic approach requires a detailed consideration of such an important factor in the declaration procedure as the deadline for submitting a customs declaration.

In order to simplify customs operations, a preliminary, temporary, incomplete, periodic declaration is introduced.

The national customs policy is closely related and directly or indirectly submits to the customs policy of many international organizations, in particular, such as the World Trade Organization and the World Customs Organization.

The effective implementation of customs operations is one of the main manifestations of a high degree of development of the logistics system in terms of the formation of an international transport complex while ensuring national security of the state.

The organization of the transport process should be based on the timely identification, prevention and neutralization of external and internal threats to national security, the protection of the sovereignty and territorial integrity of Ukraine, the security of its border space, the strengthening of Ukraine's position in the world, maintaining an adequate level of defense potential, and ensuring socio-political stability society, improving the system of state power.

One of the features of the current stage of the development of the foreign trade system is the rapid increase in the volume of trade flows that require proper regulation in the conditions of logistical integration, the deepening of interdependence between states, due to an increase in production forces and scientific and technological progress. Therefore, it is advisable to gradually overcome trade barriers and the free movement of goods through the territory of Ukraine. 
A prerequisite for the successful functioning of the customs transport system, based on fundamental national interests, in accordance with which the directions and priorities of state policy are determined, is the active entry of Ukraine into the world political, economic, and legal space.

Considering the peculiarities of Ukraine's geopolitical location, dependence on energy imports, and the structure of the transport complex, international cooperation in the field of customs administration of the goods distribution process is considered an important aspect of the country's effective development in terms of the development and use of a logistics concept for organizing the movement of goods across the customs border of Ukraine. One of the directions of the customs policy is the creation of favorable conditions for the progressive development of goods turnover and passenger traffic when developing methods for organizing the transport process based on the principles of logistics, taking into account the adaptation of national legislation in the customs sphere to international standards.

Customs policy is focused on ensuring food security, protecting the domestic market from low-quality imports, which could adversely affect the state of national consumers, producers, and the environment.

It is important to note the fiscal orientation of the customs policy, which ensures an increase in revenues to the state budget to meet the internal needs of the state.

Achieving the stability of the logistics process of goods distribution largely depends on the effectiveness of customs and transport regulation.

The introduction of balanced, stable technologies of customs control and customs clearance creates the conditions for the stable functioning of the logistics system, its strengthening, helps to accelerate the process of goods distribution, develop the export potential of domestic products, deepen integration in the European and world systems and enhance participation in international customs organizations.

The successful functioning of the customs authorities, as part of the logistics system, involves the introduction of advanced technologies in practice, as well as the selection of the optimal structure of customs administration and the option of deploying units in the state, which will increase the efficiency of work by reducing the time of customs control and clearance of goods, vehicles and other items moving across the border of Ukraine.

These actions should be carried out taking into account the requirements of the World Trade Organization, the purpose of which is to reduce trade barriers and facilitate the exchange of goods and services between countries.

The regulation of the process of product distribution in the context of a logistic approach should be aimed at the achievement by the state of certain advantages at the international level. However, the country should pursue a policy to counteract the influence of negative factors and minimize losses caused, actively use the world experience in developing systems for organizing goods distribution and technologies for managing them using the advantages of 
modern forms of international construction of customs transport systems. These actions presuppose a so-called selective protectionism policy, in accordance with which the state protects consumer goods markets from foreign competition by using tariff and non-tariff instruments.

Conclusions. Customs has a domestic focus, which is determined by the establishment of a specific procedure for moving goods across the customs border of Ukraine using customs regulation tools.

Since customs is directly organized and implemented by customs authorities, they are the main factor in ensuring customs security and state interests, taking into account the principles of logistics.

The rational use of the logistic concept of product distribution will create conditions for the activation of domestic scientific, technical and innovative potentials, attracting enterprises to effective cooperation; the introduction of a mechanism for the conservation and restoration of intellectual, energy, labor, natural resources in the territory of the state and stimulation of their most efficient use; ensuring a balanced logistics system, taking into account internationally recognized measures to facilitate trade, increase the country's transit attractiveness, accelerate trade and passenger traffic through the customs border, and prevent the importation of low-quality goods into the territory of the state, the use and consumption of which is dangerous.

\section{REFERENCES}

1. Pruss V.M. Orhanizatsiya mytnoyi spravy v Ukrayini: [navch. posibnyk] / V.M. Pruss, V.M. Piters'ka. O.: Feniks, 2009. 254 s.

2. Piterska V., Kolesnikov O., Lukianov D., Kolesnikova K., Gogunskii V., Olekh T., Shakhov A., Rudenko S. Development of the Markovian model for the life cycle of a project's benefits. Eastern-European Journal of Enterprise Technologies, 2018, 5/4 (95), $\quad$ pp. 30-39. https://doi.org/10.15587/17294061.2018 .145252

3. Shakhov A.V., Piterskaya V.M. Optimizatsiya tarifnogo regulirovaniya tamozhenno-transportnoy deyatel'nosti Ukrainy // Tamozhnya i VED. 2008. № 7. S. 183-195.

4. Piterskaya V.M. O problemakh razvitiya nauchno-tekhnologicheskikh parkov v Ukraine / V.M. Piterskaya // Problemi tekhniki: Naukovo-virobnichiy zhurnal. Vip.3. Odesa: FOPKukosh S.N., 2012. S.104-114.

5. Piterskaya V.M. Metodika transportno-tamozhennogo obespecheniya razvitiya portov Ukrainy / V.M. Piterskaya, A.V. Shakhov // Visnik ONMU: Zbirnik naukovikh prats'. Vipusk 26. Odesa: ONMU, 2009. S. 172-179. 
ВІСНИК

ОДЕСЬКОГО НАЦІОНАЛЬНОГО

МОРСЬКОГО УНІВЕРСИТЕТУ

№ 3 (60), 2019
HERALD

OF THE ODESSA NATIONAL

MARITIME UNIVERSITY

6. Piterskaya V.M. Method of transportation system capacity determination considering cargo flow forecasting / V.M. Piterskaya // Вісник ОНМУ: Зб. наук. пращь. Bun. 1 (40). Одеса: OHMY, 2014. C.176-183.

7. Piterskaya V.M. Energeticheskaya model' upravleniya tsennost'yu proyektno-oriyentirovannoy organizatsii / V.M. Piterskaya, M.O. Bokareva // Vostochno-Yevropeyskiy zhurnal peredovykh tekhnologiy. Vypusk 1/10 (61) ch.3. Khar'kov: Tekhnologicheskiy tsentr, 2013. S.199-203.

8. Shakhov A., Piterska $V$. The development of the risk management mechanism for innovation project. EUREKA: Physics and Engineering, Company «Scientific Route», Tallin, Number 3, 2018, pp. 12-20.

9. Piterska, V., Lohinov, O. and Lohinova, L. (2019) «MECHANISM FOR FORMING AN EFFECTIVE PORTFOLIO OF RESEARCH PROJECTS OF INSTITUTION OF HIGHER EDUCATION», INNOVATIVE TECHNOLOGIES AND SCIENTIFIC SOLUTIONS FOR INDUSTRIES, (3 (9), pp. 99-108. https://doi.org/ 10.30837/ 2522-9818.2019.9.099.

10. Piterska, V., Lohinov, O. and Lohinova, L. (2019) «PORTFOLIO METHOD OF SCIENTIFIC ACTIVITY MANAGEMENT OF HIGHER EDUCATION INSTITUTIONS》, INNOVATIVE TECHNOLOGIES AND SCIENTIFIC SOLUTIONS FOR INDUSTRIES, (2 (8), pp. 86-96. https://doi.org/10.30837/25229818.2019.8.086.

11. Piterska, V.M., Shakhov A.V. Development of the Methodological Proposals for the Use of Innovative Risk-Based Mechanism in Transport System. International Journal of Engineering \& Technology (UAE), 2018, Vol. 7 (4.3), pp. 257-261.

12. Piterskaya V.M. Transportation system development modeling subject to customs control of cargo flows / V.M. Piterskaya // Constanta Maritime University Annals, Year XIV. Vol. 20. Constanta: «Nautica» Publishing House, 2014. P. 311-315.

Стаття надійшла до редакиії 18.11.2019 